\title{
Demand for chilli varietal products features in Warud taluka of Amravati district
}

V.K. PATIL

Received : 15.07.2015; Revised : 05.08.2015; Accepted : 06.09.2015

\begin{abstract}
The objective was to identify the vegetable pattern and quality preferences of chilli crop for Ankur Seeds Pvt. Ltd. The result revealed that the selected vegetable grower belongs to small farmer category having good irrigated land with good economic vegetable production. They are sticked up with the well known varieties of the vegetable with preferences to high productivity.
\end{abstract}

KEY WORDS : Chilli, Demand chilli, Quality preference, Varietal pattern

How to cite this paper : Patil, V. K. (2015). Demand for chilli varietal products features in Warud taluka of Amravati district. Internat. J. Com. \& Bus. Manage, 8(2) : 171-173.

Email: mr.esctacy2008@gmail.com 